\title{
LSE Research Online \\ Frido Wenten \\ Does it matter what workers do? The role of workers' relational agency in the hybridisation of TNC subsidiaries in China and Mexico
}

\section{Article (Accepted version) (Refereed)}

Original citation: Wenten, Frido (2017) Does it matter what workers do? The role of workers' relational agency in the hybridisation of TNC subsidiaries in China and Mexico. International Journal of Automotive Technology and Management, 17 (2). p. 190. ISSN 1470-9511

DOI: $10.1504 /$ IJATM.2017.084803

\section{(C) 2017 InderScience}

This version available at: http://eprints.Ise.ac.uk/86957/

Available in LSE Research Online: March 2018

LSE has developed LSE Research Online so that users may access research output of the School. Copyright (C) and Moral Rights for the papers on this site are retained by the individual authors and/or other copyright owners. Users may download and/or print one copy of any article(s) in LSE Research Online to facilitate their private study or for non-commercial research. You may not engage in further distribution of the material or use it for any profit-making activities or any commercial gain. You may freely distribute the URL (http://eprints.Ise.ac.uk) of the LSE Research Online website.

This document is the author's final accepted version of the journal article. There may be differences between this version and the published version. You are advised to consult the publisher's version if you wish to cite from it. 


\title{
Does it matter what workers do? \\ The role of workers' relational agency in the hybridisation of TNC subsidiaries in China and Mexico
}

\author{
Frido Wenten ${ }^{1}$ \\ fw4@soas.ac.uk
}

\section{Abstract}

This article questions if the issue of hybridisation - or convergence and divergence - in the operations of global car producers is sufficiently addressed on the level of ideal typical "productive models" or other forms of static ideal types. Arguing that there are difficulties in accounting for dynamic change and process, I suggest a shift in attention to processes of relational agency between social agents on and beyond the shop floor. Based on empirical evidence on the Chinese and Mexican subsidiaries of one of the largest global car manufacturers, I argue that in these relational processes worker agency has to be considered as a factor that shapes institutional change and variety, as well as the actual performance of shop floor institutions.

\section{Keywords}

automotive industry; hybridisation; convergence; divergence; workers; labour; agency; China; Mexico.

\section{Introduction}

In 1990 the MIT study The Machine that Changed the World (Womack et al. 1990) proclaimed the inevitable convergence of the global automotive industry in a "lean production" paradigm. At the same time, a parallel German research project (Jürgens et al. 1989) more cautiously suggested that the differences between global auto producers' production and sales strategies might not be overcome so easily. Over time the "lean production" hypothesis would be challenged by the idea of persistent divergence in company-specific "profit strategies" and "productive models" (Boyer \& Freyssenet 2002; Freyssenet 2009). Rather than a uniform driving force towards convergence, the core assumption behind these twin-

\footnotetext{
${ }^{1}$ Frido Wenten is ESRC Postdoctoral Fellow of the "Global Challenges Research Fund" at the Department of Development Studies, School of Oriental and African Studies (SOAS); and Fellow at the Department of International Development, London School of Economics and Political Science (LSE).
} 
concepts was that automotive manufacturers develop their internal rules, organisational principles and market orientation in accordance with the national institutional incentive structure, or "matrix", of their respective home country (apart from Boyer \& Freyssenet 2002; and Freyssenet 2009; particularly Streeck 1992; Streeck \& Kenworthy 2005).

Consequently arising from this assumption was the puzzle of what occurs when a transnational company with internal institutions modelled after the matrix of home country A opens a subsidiary within the different matrix of destination country B. This question triggered research interests beyond the "productive model" approach proper, in particular on Japanese TNCs (e.g. Abo 1994; Boyer et al. 1998; Kumon \& Abo 2004). The shared conclusion was that as a rule rather than full application of the parent company model, some form of adaptation to local specificities occurs, which results in a hybridised model for the subsidiary plant. Dominant in the aforementioned studies has been an interest in deciphering the actual elements that converge or diverge between parent and subsidiary plant, in order to construct from their different combination certain patterns, models or types. This procedure has enabled constructive and increasingly complex crossand within-company comparisons (e.g. Boyer et al. 1998; Freyssenet 2009). What has attracted less attention though is the role of agency in the hybridisation process - for example in strategic decision-making or the day-to-day operations of a plant - that could help to move from comparative static modelling to causal explanation. What is more, the advances that have been made in this direction for example by Kostova and Roth (2002) or Becker-Ritterspach (2009) - have introduced a perspective on processes of agency that focuses on vertical interactions between management of parent and subsidiary plant, and/or on the interaction of management and (local) policy makers. What has remained largely absent is an analysis of the agency of non-elites - in this case: workers. ${ }^{2}$

In this article I argue that worker agency - in relation to that of other agents - has the potential to deflect managerial strategy into unintended consequences; and defy the purpose of shop floor governing institutions. On the one hand, certain cataclysmic eruptions of relational agency evoke institutional changes that are inexplicable within an institutionalist framework alone. And on the other, diverging forms of everyday practices of workers and managers on the shop floor can alter the actual performance of institutions, helping us to explain actual converging or diverging dynamics without equating these to functional effects of a particular institutional design. In other words, the actual performance of institutions or "productive models" - beyond their purposive design - hinge upon

\footnotetext{
${ }^{2}$ This is not to say that the need to take worker agency into account on a theoretical level has not been acknowledged (e.g. Boyer 1998). Empirically though, the impact of worker agency has rarely been researched - and if so, has mostly been substituted for an analysis of the agency of union or work council representatives (e.g. in Jürgens et al. 1989).
} 
how horizontal and vertical relations between managers and workers are constituted and pan out in reality.

After a revision of the shortcomings of the "productive model" and similar approaches, the remainder of the article contrasts comparative statics on technological composition; remuneration systems; the organisation of work and time; and training processes at one of the largest global car producers' subsidiaries in China and Mexico to past and present agency within and between their workforce and management. It descends via three sections from a more significant instance of worker agency shaping institutional change; to the less visible impact of everyday forms of relational agency on the shop floor; and to the contrasting case of absent worker agency in shaping the technological composition of the production process. The information it draws on has been obtained through shop floor observations and over 80 interviews during two sixmonths periods of fieldwork in each Mexico and China between September 2012 and September 2013. Problem-centred interviews were carried out with participants chosen through purposive sampling, according to function and status: managers, union personnel, permanent, and temporary workers. This choice was made due to restricted access, at the cost of a statistically non-representative sample. To approximate analytical representativeness of factual information, interviews were undertaken up to a point of saturation, when common themes became visible and information overlapped significantly; and the information was, where possible, triangulated with company or other official records, as well as secondary data and existing studies (e.g. Lüthje et al. 2013; Zhang 2014; Juárez Núñez et al. 2005).

\section{Limitations of ideal-typical modelling}

Profit strategies and productive models are the result of decades of inductive research and should be taken as "a largely unintentional process for creating an external relevancy and internal coherency for [...] technical, organisational, managerial and social changes" (Boyer \& Freyssenet 2002, p.23). Once conceptualised, they are essentially ideal types - or "heuristic devices" (Hollingsworth \& Boyer 1997, p.20) - that give meaning to a complex reality by providing a template against which historical analogies and deviance can, in Weber's terms, be "comparatively measured" (Weber 1988, p.199). As Weber recognised, this procedure bears the danger of "telescoping theory and history" (ibid. p.204), that is, of tailoring history to the properties of the ideal type. And what he suggested as a solution was to emphasise that logical conceptualisation and empirical reality are two radically different and incommensurable domains. ${ }^{3}$

3 This notion seems to be shared by at least some proponents of the institutionalist tradition. Hollingsworth and Boyer for example argue that ideal types "are not meant to be descriptive 
On this basis Weber suggested a procedure shared by the "productive model" approach - and the institutionalist tradition more generally - that I call typologism: "comparative measuring" results in the construction of new idealtypes, or at least sub-types, in each case of historical deviation. ${ }^{4}$ Reality is ordered through an ever-increasing number of types, models and regimes, which combine common elements in different ways. Surely this method is a powerful tool to debunk myths of convergence in one single ideal type - such as the prediction of the homogenous spread of lean production across the entire automotive industry (Womack et al. 1990). And it also gives us a certain "roadmap" as to where to look for significant elements affecting the operations of a certain company. However, as in Weber's method of ideal type construction, there is a serious difficulty to explain causality and process from the static character of a productive model. Even if we had the most complete list of elements that in their differential combination make up individual ideal types, it will never be possible from within this logic (alone) to actually find explanations as to why and how this type emerged or transformed in the way it did. Taking this back to the initial question, there is a range of factors that suggest either a tendency towards convergence or towards divergence of productive models between a parent company and its subsidiaries. Table 1 lists a few of these factors, which could however be extended at will.

\begin{tabular}{|l|l|}
\hline Convergence & Divergence \\
\hline Technological Rigidities & Cost and Profitability \\
\hline $\begin{array}{l}\text { Shared Platforms/Modular } \\
\text { Production }\end{array}$ & Quantity/Quality \\
\hline Global standards (e.g. ISO norms) & $\begin{array}{l}\text { Ownership Structure (Joint } \\
\text { Ventures?) }\end{array}$ \\
\hline Free Trade Agreements & Local Market Structure \\
\hline Home Country Institutions & Local Institutions \\
\hline Global Suppliers & Local Suppliers \\
\hline Open Capital Markets & Labour Supply and Skills \\
\hline
\end{tabular}

Table 1: Factors suggesting convergence or divergence

Factors such as shared platforms, technological rigidities (e.g. operations requiring particular machinery), global norms, the impact of the home country institutions on corporate governance etc. suggest that companies will reproduce

statements about specific firms, industrial sectors, or individual firms at specific periods of time. Rather, they are heuristic devices to sensitize us to possible interrelationships that might exist among a broad set of variables or social categories." (Hollingsworth \& Boyer 1997, p.20)

${ }^{4}$ In another self-criticism, Hancké has pointed out: "One of the problems with such expanding typologies is that ultimately one could claim that every capitalist country has produced its own 'variety', in which at least one institution or combination of institutions is historically specific, and therefore different from other related types." (Hancké 2009, p.15) 
the productive model of their headquarters abroad. Cost differentials, different market structure and size, local regulations and norms, a different model range, different ownership structure in case of joint ventures etc. on the other hand are factors that suggest a high degree of divergence in the productive model of foreign subsidiaries. Naturally, the most likely outcome in any empirical case is some form of hybridisation that combines converging and diverging elements (Abo 1994; Boyer et al. 1998; Kumon \& Abo 2004; Becker-Ritterspach 2009) - but it is not from establishing a list of factors itself, or from their particular combination, that we can draw conclusions as to why and how a hybrid productive model emerges.

If these models are strictly speaking the final result and not the starting point of historical-empirical inquiry, then factors external to the productive model must exist that explain its emergence and transformations. This paper suggests that human agency, particularly in a relational form between social groups, becomes an important analytical issue for (at least) two reasons. On the one hand, to demonstrate a causal relationship between institutions/productive models and behaviour, the effects of the institutional matrix require occasional empirical reference to what social agents "actually do" with the constraints and options provided to them. On the other hand, in order to explain the emergence and change of institutions/productive model, the reverse relation needs to be examined, namely how what social agents "actually do" transcends the institutional matrix, which might lead to unintended dysfunctionalities or trigger institutional adaptation.

\section{The case}

German Company X developed into one of the largest global producers of low and medium-priced passenger cars after World War II. With sales of 5.04 million units in the first half of 2015 it was briefly the world's largest car manufacturer (Cremer \& Funakoshi 2015), uniting twelve independent motor vehicle brands under one company group and running production facilities in 21 countries. In the productive model approach, Company X has been said to pursue a "volume and diversity" profit strategy, characterised by the mass production of a wide range of models. This in turn rests on a "productive model" of polyvalently skilled workers, quickly adaptable machinery, a high degree of outsourcing, and the ability to quickly integrate innovations developed elsewhere (Boyer \& Freyssenet 2002, chap.6). Due to its public-private ownership structure at the headquarters, its cooperative industrial relations and extensive collective agreements Company $\mathrm{X}$ has also been heralded as an archetype of German "neo-corporatism" (Streeck 1992; Jürgens 2009). 
Company X opened its first Mexican and Chinese plants in 1964 and 1984 respectively, mainly with the aim of accessing the shielded domestic markets of the two countries (Bennett \& Sharpe 1985; Thun 2006; Chin 2010). In 2015 the company group operated three manufacturing plants in Mexico and fifteen in China, all of which had been opened after 2009 (Figure 1).

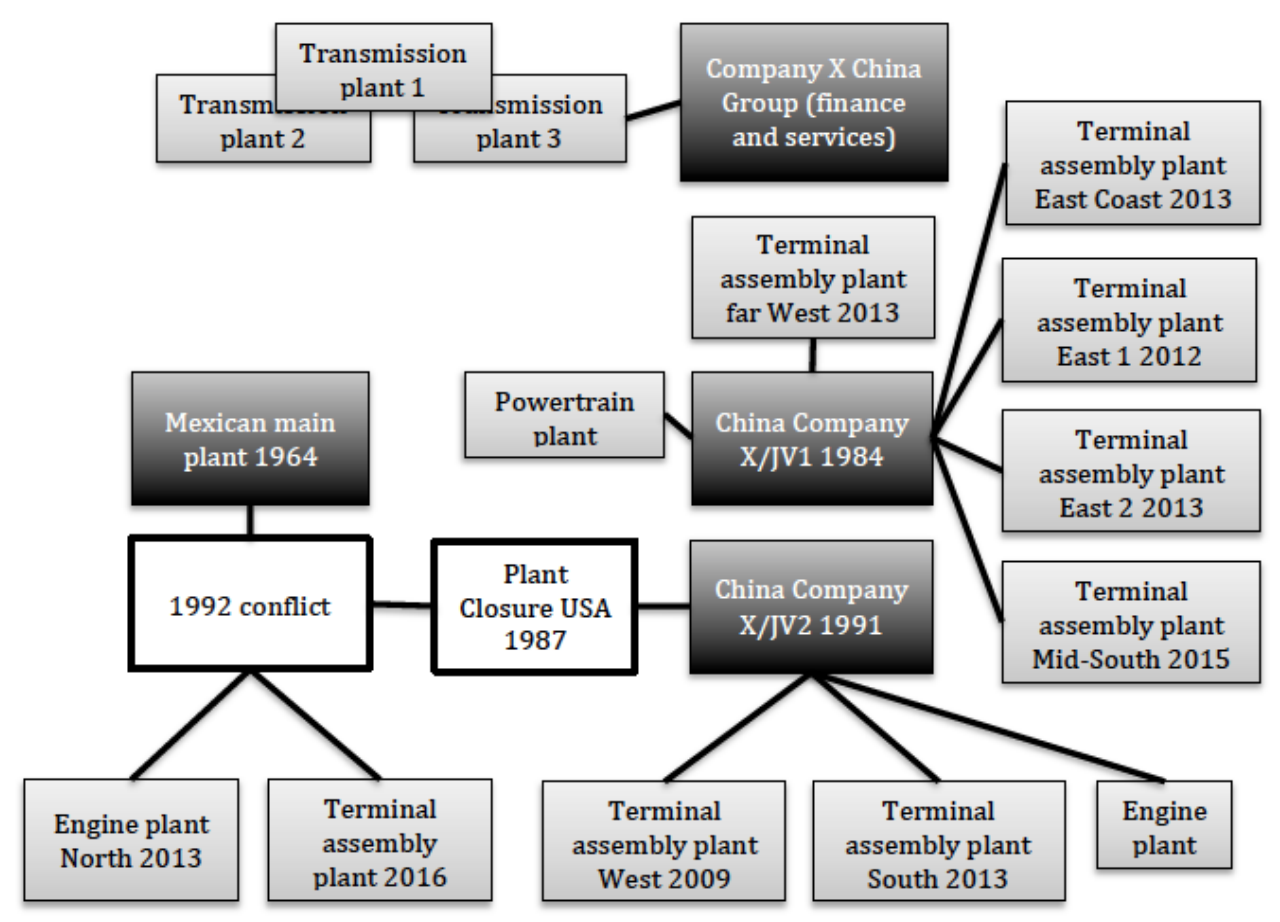

Figure 1: Company X corporate structure in China and Mexico, 2015

Both the Mexican and Chinese main plants are comparably large, with more than 10,000 direct and 5,000 indirect employees - the Mexican main plant employed a total of about 18,000 workers in 2012, while the main plants of the two join ventures of Company X in China had workforces of around (JV1) and above (JV2) 20,000 in 2013. Around a quarter of direct employees were temporary workers in Mexico and at JV2, with no data being available for JV1. ${ }^{5}$ These workers were directly hired by Company X in Mexico, while in China they were "dispatched" by labour agencies. ${ }^{6}$ The share of female workers in production was low, between $5 \%$ in Mexico and 2\% at JV2, but in administrative and service jobs it was around twice as high in the Chinese JVs as in Mexico (24/21\% versus 12\%). The subsidiary assembly plants in China were all significantly smaller, with projected workforces

\footnotetext{
5 Officially JV1 does not employ temporary agency workers. This, however, is only partly correct, as the Chinese side of the joint venture runs its own labour agency. Due to the particular ownership structure the dispatch workers it hires do not appear as such in official statistics.

${ }^{6}$ To speak of permanent employment for the Chinese case is slightly misleading, because directly employed workers also only possess temporary (one to three year) contracts, which are however customarily renewed (see also Jürgens \& Krzywdzinski 2015).
} 
of around 6,000 to 8,000 direct workers - none of these plants ran at full capacity yet in 2013. Similarly, the new Mexican assembly plant that began to be staffed in 2016, would have a smaller workforce. The majority of the workforce was composed of residents from the surrounding areas, while in China temporary workers could also be hired from distant provinces via recruitment agencies. ${ }^{7}$ The most significant difference between the Mexican and Chinese ventures, however, was the age composition of the workforce, with an average age of over 45 in Mexico and around or even below 30 in China. This was mainly due to the maturity of the respective plant and continuous expansion and hiring in China. Temporary workers were in both cases in their early twenties, as they were hired from vocational schools or high schools. ${ }^{8}$ Concealed in the Chinese case is however the fact that at least JV2 made extensive use of student interns from vocational schools, who worked at the plant for either six months or a year and were in their late teens or early twenties. Zhang (Zhang 2014, p.70) estimates that interns can make up about a third of the workforce in labour intensive departments, which was confirmed in my interviews. ${ }^{9}$

There were two further aspects that set the cases apart. First, vertical relations within management differed, due to the joint venture structure in the Chinese case. While the Mexican plant was staffed with single (usually Mexican) department heads, each department in the Chinese joint ventures was headed by both a Chinese manager of the respective SOE, and a German manager of Company $\mathrm{X}$. Exempted from this rule were Human Resources. This meant that managerial decisions in China did not mirror Company X decisions in a one-to-one fashion and that the area of employment relations in particular was beyond immediate influence (but also responsibility) of the German side. Second, Company X in Mexico had an independent enterprise union with a rich tradition of rank and file activism, strikes and campaigns - as well as union infighting and conflicts between grassroots movements and union leaders. The Chinese trade union on the other hand was tightly controlled by party and management, which is typical for branches of the All-China Federation of Trade Unions in state owned enterprises. Neither workers nor union leaders, who held former or parallel managerial positions, had any interest in using the union as a vehicle for interest representation or worker agency. ${ }^{10}$ These relations did neither differ significantly between the two JVs nor between subsidiary plants in different geographic areas of China. While most plants of JV1 are concentrated in the same province, JV2 has subsidiaries in West and South China. Because it is a large centrally controlled

\footnotetext{
7 The trade union chairman of a JV2 subsidiary estimated that around $90 \%$ of the workforce were local residents; JV2U1.

8 This is not a statistically representative result, but an estimate from interviews with workers.

${ }^{9}$ It was not possible to clarify how these interns count towards the overall employment figures.

10 Interviews with workers JV1DW1,4 JV1FW2,3,5 and JV2FW1,2; interviews union officials JV2U1,2.
} 
SOE, its trade union leaders have sufficient leverage to refuse adaptation to the more reform-oriented environment in South China. ${ }^{11}$ If over time regional differences in worker agency - for example higher labour turnover and a higher propensity to strike in South China (Pringle 2011; Chan 2014; Elfström \& Kuruvilla 2014) - will have an impact on the recently opened Southern subsidiary of JV2 remains to be seen.

\section{Institutional change and relational agency - The 1992 strike in Mexico as a watershed}

Before I shed more light on the shop floor institutions and their performance in Company X's plants in China and Mexico for more recent times, it is crucial to mention the in many regards decisive turning point in the organisation of the Mexican main plant. In 1992 a newly elected union leadership signed a secret agreement with Company $\mathrm{X}$ to experiment with meritocratic remuneration schemes, teamwork, and outsourcing. This sparked a month-long wildcat strike against management and union leadership, during which the enterprise fired the entire workforce. After blacklisting over 1,000 activists it rehired the remaining 12,000 workers under a new collective contract that introduced the aforementioned institutions across the board. It also imposed new union statutes that eliminated the layer of shop stewards, who had been the backbone of preceding union strength. Crucial to the escalation of the conflict was that for the preceding five years labour struggles had prevented the implementation of structural and institutional changes, which the enterprise envisioned in preparation for North American exports after the closure of its sole US production site in 1987 and the dawn of NAFTA. ${ }^{12}$

The analytical relevance of this event resides in two interrelated aspects that demonstrate the explanatory relevance of relational agency. First, the event itself was neither predictable by the pre-1992 institutional matrix, nor could the latter explain the behaviour and strategies of different stakeholders during the conflict (i.e. structures/institutions fail to explain event and behaviour). And second, the actual institutional change that was implemented after the conflict - discussed in more detail in the next paragraphs - is not explainable post hoc as a functional transition, but instead as a result of the strategic interaction of the different stakeholders involved (on this point I share much of the argumentation of Pries 1993). Some of the old institutions where abolished, others transformed, and new ones established - why this occurred in the form it did can only be explained from

\footnotetext{
11 Interviews city- and province-level union leaders South China, SCU1, 2.

12 This conflict has been well documented, with different analytical conclusions (Juárez Núñez 1993; 2006; Pries 1993; Healy 2008; Wenten 2016). Unfortunately the details of the conflict are beyond the scope of this article.
} 
the interactions of policy makers, managers and workers (i.e. institutional change is driven by relational agency). ${ }^{13}$

While we can therefore speak of an impact of worker agency on institutional change in the Mexican case, there is no equivalent event in the history of the Chinese JVs. The initial implementation of shop floor institutions in the Chinese case has for the most part been at pure managerial discretion ${ }^{14}$ - which does however not preclude that worker agency might have an impact on their actual day-to-day functioning.

\section{Divergence - Conflict and compliance in the organisation of production}

Beyond the occurrence of watershed events, I will emphasise that the performance or effects of shop floor institutions, once implemented, depend on how everyday forms of relational agency unfold. Essentially I suggest that divergent forms of this agency cause a divergence in institutional performance. The particular ways production was organised in the two cases depended the actual power of managers and workers to influence strategic decisions and dayto-day operations in their favour. On the basis of a closer analysis of remuneration systems, training practices and the organisation of work on the shop floor, I will stress three observable forms of worker agency deflecting managerial interests into unintended results. These forms are routinized bargaining practices through established union structures; open or silent non-cooperation and refusal; and exit strategies. These forms correspond roughly to thematic areas of remuneration; the organisation of work and time; and training.

\subsection{Contracts and remuneration}

In both China and Mexico, Company X had implemented meritocratic wage systems. However, wage setting was a unilateral decision of the Chinese management in JV1 and JV2 - although the union leadership was consulted in the decision making process - while in Mexico collective agreements and union-led wage bargaining remained important institutions. The 1992 conflict, however, had severely altered and curtailed union power. In both cases, the real workings

\footnotetext{
13 The emphasis on a watershed event differs from the leitmotiv of "punctuated equilibrium" (North \& Weingast 1989; Weingast 2002) or "path-dependency" approaches (Mahoney 2000) in that the event is not contingent, and neither is its result arbitrary nor "relatively determined" - but instead, it is the outcome of a specific balance of forces between different social agents and the processes of relational agency between them.

${ }^{14}$ That this has worked itself out rather smoothly - at least in the post-WTO period, when the restructuring of SOEs and related protests had been concluded - can also partly be attributed to the fact that in an expansive dynamic of opening new facilities new institutions can be implemented in the absence of any worker influence (in China).
} 
of meritocratic remuneration depended on their implementation in the particular force field of management-worker relations - and as these differed, so did the use and effects of broadly similar remuneration systems.

Wages, working hours and tasks in Mexico were directly regulated by the company-specific collective agreement, which was subject to annual renegotiation. In 2012 workers were grouped into 23 bands of twelve pay grades, ranging from $\$ 5,280$ to $\$ 18,156$ per month, depending on work area, status (worker, specialist, team leader) and performance. ${ }^{15}$ These wages were the second highest in the automotive industry in Mexico (Covarrubias 2014), and well above the 2012 Mexican minimum wage of $\$ 1,911$ per month. ${ }^{16}$

In the Chinese case, collective agreements had the status of a non-negotiated baseline for management-union relations, established at the foundation of the enterprise. Wages at both JV1 and JV2 were regulated in individual contracts, which subdivided them into base pay, benefits and allowances and the so-called "floating wage" - the latter mainly referring to efficiency wages and premiums. ${ }^{17}$ Blue collar workers at JV1 were subdivided into ordinary and skilled workers (Facharbeiter); and at JV2 into five separate, but partly overlapping pay bands increasing with rising skill level and complexity of tasks (for a detailed discussion see Jürgens \& Krzywdzinski 2016, p.209ff.). In the summer of 2013, the base wage for ordinary workers was $¥ 2000$ at JV1; and $¥ 1,300$ at JV2, which in both cases was about $¥ 200$ above the local minimum wage. The average monthly net income at JV1 was $¥ 4,000$ to $¥ 5,000$ (USD 650 -810) for ordinary formal workers and $¥ 3,000$ to $¥ 4,000$ (USD 485 -650) for dispatch workers in 2013; at JV2 the figures were $¥ 3,500-4,500$ (USD 565-730) and $¥ 2,800-3,200$ (USD 450-515), respectively. ${ }^{18}$ This implies that up to $50 \%$ (JV1) or even $60 \%$ (JV2) of formal workers' monthly net earnings could depend on potentially variable overtime

\footnotetext{
15 Company X in Mexico divides the workforce into three categories: ordinary workers (técnicos); "specialist" workers (especialistas, similar to the German Facharbeiter), such as maintenance workers; and team leaders. Ordinary workers can climb up a scale of sixteen levels; and their team leaders an additional four. Specialists have an entry salary equivalent to the tenth level for ordinary workers and can increase their salary along another eleven levels. Specialist team leaders are grouped into two levels at the top of the pay grade. The lowest level salary for an ordinary team leader is 2.3 times that of the lowest level salary for an ordinary worker; for specialists the ratio is $2: 1$.

16 Different from China, it is not merely difficult but sheer impossible to survive on the Mexican minimum wage as a single source of income.

17 In some cases "floating wage" also includes aspects of a "functional wage", i.e. premiums based on a worker's rank (Lüthje et al. 2013, p.67). The term "floating wage" dates back to China's economic reforms in the 1980s that allowed SOEs to retain a certain percentage of their profits for redistribution amongst the workforce. The percentage of the floating wage in the overall wage bill was supposed to be fixed - initially at no more than $5 \%$, which by 1993 had already increased to $23.3 \%$ on average (Meng 2000, p.83f.).

18 Information gathered from workers' payslips and interviews with workers and managers.
} 
benefits, individual or company performance. ${ }^{19}$ Due to the high number of orders, this share in itself was however relatively stable. Wages at Company X compared favourably to Asian (i.e. Japanese and Korean) joint ventures with workers' median annual cash income being $¥ 42,732$, but were rather low if compared to other European and American companies (¥62,354) (Puxin Management Consulting Co., in Zhang 2014, p.76).

Although both Chinese and Mexican remuneration systems were strongly based on performance evaluations, their actual functioning compares quite differently. In Mexico workers' climbing the pay grade depended fully on individual appraisals, but the daily wage associated with each pay grade/band was predetermined by the collective agreement and was re-negotiated each year. Any additional benefits, allowances, premiums and bonuses were calculated as ratios of the respective worker's daily salary. This system was the result of the union's defeat in the 1992 conflict and the consequential abolition of seniority wages. While the allocation of individual workers to their respective grade/band was subject to (monthly) meritocratic evaluations, collective bargaining over annual wage increases and the number and spread of pay grades was institutionally retained. Unless the enterprise was able to impose a pay freeze, all workers would receive an annual nominal pay rise as an effect of collective bargaining.

In China, most premiums and overtime pay were similarly calculated as percentages of the base pay, but the latter was not subject to regular collective negotiations. Upon hiring, workers were placed in certain pay grades according to skill level, tasks and employment status. In addition to premiums from monthly individual appraisals and overtime benefits, a major part of workers' income depended on company performance-based bonuses distributed at the discretion of the enterprise in the form of double wages and/or mid-year or year end bonuses (the latter alone can account for up to 25\%, Lüthje et al. 2013, p.55). ${ }^{20}$ Different from temporary workers in Mexico, dispatch workers in China were not eligible for the full amount of premiums and bonuses. As a consequence, salaries amongst individual workers showed a wide spread (a point stressed as well by Jürgens \& Krzywdzinski 2016, p.214ff.); and there was no automatic progression in income of any sort.

The implications were twofold. On the one hand, workers in both cases complained about nepotism and a lack of transparency in the appraisal process,

\footnotetext{
${ }^{19}$ Calculations based on workers' payslips; author's field notes; interviews with Chinese workers JV2FW1, JV2DW2,3; Chinese managers JV2CM1,2,3; German senior manager JV1GM.

${ }^{20}$ Here it is important to distinguish between "premiums" that depend on individual appraisals; and "bonuses" depending on company performance. Bonuses were distributed to the workforce in times of high sales, without transparent procedure and without workers having a formal entitlement to them. Complaints at JV1 arose during the financial crisis, when the enterprise reduced these bonuses, interview worker JV1FW4; online forums.
} 
although these grievances were more widespread amongst older Mexican workers that had experienced the seniority system than amongst Chinese workers. ${ }^{21}$ And temporary and dispatch workers criticised the limited prospect for permanency or career progression. On the other hand, these grievances were partly channelled into complaints to the union administration in Mexico; while in China workers either accepted these practices or sought other forms of coping strategies, such as a venting their anger in internal and public online forums, a reduction of effort and, in the case of dispatch workers, exit. However, that the union in Mexico had the institutional leverage to influence the overall pay grades did not necessarily translate into benefits for the workforce either: in 2002 it agreed to an introduction of five lower pay grades that cut the basic entry salary by $50 \%$. This, again, was a deliberate choice by the union to pre-empt a replay of the 1992 events:

"Huge conflicts have not occurred since 1992, because with us the enterprise achieved a new agreement - the new wage levels that allowed it to lower labour costs. Why did we sign this agreement in 2002? Because we thought it was better to make a deal than to risk another conflict."22

In sum, in Mexico the continuous relevance of the union in collective bargaining procedures created a co-determined mechanism for regular wage increases that ran parallel to an otherwise individualised meritocratic system. However, the crucial point is that this institutional legacy in itself was mere potentiality or idle capacity - it still depended on the actual constellation between union leadership, rank and file workers and management to what effect these institutions were actually mobilised. In China, on the other hand, management retained full discretion over wage setting and rather chose to keep workers motivated by redistributing bonuses at will. This system seemed to have worked considerably well, given that Company $\mathrm{X}$ in China has grown near continuously and is usually one of the best paying employers in the region. It remains speculative if a majority decision-making power of the German side in the cases of JV1 and JV2 would have altered this arrangement.

\subsection{Organisation of work and time}

Although within the global automotive industry teamwork has been applied in manifold forms (Babson 1995; Kochan et al. 1997; for a conceptual overview on

\footnotetext{
${ }^{21}$ My interviews and evaluation of online message boards suggest that there were complaints about the way performance evaluations were carried out in Company X's Chinese JVs. This contrasts with the analysis of Jürgens and Krzywdzinski (2016, p.209ff.), who stress that the transparent and fair nature of these evaluations led to widespread acceptance within the workforce. It would require better, unrestricted access and larger sampling sizes of worker interviews to answer with more confidence how workers actually viewed the appraisal system. 22 Interview former general secretary Company X union Mexico, MU2.
} 
team work see Schaper 2014), in ideal typical terms the team in a lean production paradigm should be the responsible unit not only for the fulfilment of immediate productive operations, but also for task assignment (including job rotation), quality control (including responsibility for mistakes), self-evaluation, and "continuous improvements" (CIP) of the production process. This is based on polyvalent task ranges and multi-skilled workers within each team; and a cooperative "client and supplier" philosophy between individual workers, teams and managers. On the surface, work organisation in Mexico and China resembled to lean production philosophies of teamwork and CIP. However, in practice these rules were rarely applied by the book.

In both Mexico and China teamwork was introduced and organised in a top-down fashion, either against explicit union resistance as in Mexico in 1992 - or without worker involvement throughout the gradual enlargement of productive capacity during the 1990s, as in the case of JV2. ${ }^{23}$ In both Mexico and China teams were of variable sizes (usually 1:10 or 1:15) depending on the department and workstation. Each team had a skilled worker as a team leader, who, unlike in the German plants, was in both cases not elected by the team members. In Mexico, the team leader was the worker with the highest pay grade in his team, given that he fulfilled certain performance criteria and was approved by the enterprise. In China advanced workers who passed all performance criteria could sit examinations to qualify as potential team leaders, to be appointed by the shop manager if a vacancy opened up (described in detail in Zhang 2014, p.110). In both cases the team leader was accountable to a group leader, who supervised multiple work teams and represented the lowest level of management. Quality circles were formally in place; and workers were asked to submit monthly suggestions for process optimisations, which counted towards their regular performance evaluations. ${ }^{24}$

The team leader supervised, instructed and evaluated the team members' individual performance - the latter having an immediate effect on wages and promotions. He also had the freedom to re-assign tasks within his group, while higher levels in the hierarchy could re-assign tasks across groups and overrule the decisions of team leaders. Neither in Mexico nor in China was job rotation scheduled by a transparent procedure. It occurred on an informal basis at the discretion of the team leader after consultation with, or orders from, higher-level managers. In addition, and against the principle of "waste reduction", teams at JV2 were usually staffed with a higher number of workers than required for immediate productive operations, so that there was certain flexibility for mutual help or substitution. This was likely a result of the larger amount of inexperienced workers on the production line.

\footnotetext{
${ }^{23}$ Insufficient data is available on how this process unfolded at JV1.

${ }^{24}$ Author's field notes; see also L. Zhang 2014, p.138; Montiel 2001, p.175ff.
} 
Formally, in both China and Mexico were time regimes determined unilaterally by the enterprise - the union in Mexico had lost its right to co-determine the allocation of overtime or intensification of work in 1992 - including working hours and days, shift length and rotation, and cycle time. The regular working week in Mexico was 44 hours for the day shift, 42 hours for the afternoon shift, and 40 hours for the night shift. Day and afternoon shift included a half an hour break; the night shift was thirty minutes shorter; and shifts rotated on a monthly basis. JV1 followed two different shift systems: a three shift system; and a twoshift system with regular working days of variable length between eight to eleven hours, in which workers alternated between two day shifts, two night shifts and two rest days. JV2 had a three-shift system with eight working hours and biweekly rotation and a working week of 6.5 days - that is, workers had one day off every two weeks. Cycle times were unilaterally determined by the enterprise and varied by task complexity. In newer plants in China, however, all processes were set up for a cycle time of 60 seconds.

Exhausting work rhythms were the most pronounced complaint amongst my interviewees in both China and Mexico. In Mexico, however, workers I interviewed also strongly criticised the particular work organisation for two basic reasons: a general sense of increasing competition, and a more specific frustration with job rotation and alteration of work rules being at the sole discretion of the enterprise. ${ }^{25}$ Because teamwork was introduced in Mexico against the will of the majority of the workforce there was persistent discontent with the system. The union committee elected in 2000 proposed to management to tackle the issue by involving union personnel in the co-determination of work rules again. The refusal to even consider the proposal triggered a strike, which resulted in an enlargement of the number of section stewards, and a de facto re-vitalisation of grassroots institutions, such as the general assembly, which the enterprise had abolished in its rewriting of the union statutes in 1992. However, no institutional response to workers' demand of control over work rules was made, which rather aggravated the situation of silent dissent on the shop floor - a fact that was not only confirmed in interviews with workers and academic experts, but also by the existence of clandestine groups of worker dissidents within the plant. ${ }^{26}$ The result was that management had to deal with recurring instances of worker refusal (in the forms of wildcat overtime refusals and/or complaints to the union/HR) to accept job rotations; long working hours; forced vacation in times of low orders; and cycle time reductions. For the latter the union tried to negotiate a compensatory increase in workers' salaries in an ad-hoc manner; but no new formal arrangement emerged. The actual functioning of teamwork and time allocation in

\footnotetext{
25 Interviews workers MPW2-12.

${ }^{26}$ Interviews workers MPW3,6,7,8; Interview Huberto Júarez Núñez; author's field notes.
} 
Mexico is probably best characterised as a dysfunctional stalemate, in which authoritarianism from above and evasion or resistance from below prevent institutional change either in the interest of workers or of managers. For example, despite incidents of overtime refusals and complaints did management not reintegrate the union in decisions on time allocation - but neither has it (at the main plant) been able to implement its desired introduction of time accounts, due to stern opposition from the workforce.

In Mexico the recurring back and forth between managerial authoritarianism and workers' strategies of compliance, evasion, or resistance were the determining factor in how the institutional effects of teamwork and CIP actually materialised. The enterprise thwarted workers' proactive contribution to CIP through insufficient monetary and career incentives and in particular through sustained authoritarian hierarchies, which resulted in reduced effort and participation. In practice this counteracted ideal typical institutional effects and implied that Company X in Mexico chose to operate under conditions of persistent discontent and pressure from below, while refraining from installing union- or other mechanisms that could function as safety valves.

In China an assessment of the role of worker agency in shop floor relations is ambivalent at best. While Zhang documents a small number of instances of worker refusal and suggests an image of widespread grassroots resistance (Zhang 2014), Jürgens and Krzywdzinski emphasise workforce compliance and describe shop floor relations at Company X in China as "almost a paradise for management" (Jürgens \& Krzywdzinski 2016, p.256). My observations and interviews in China suggest that a reduction of effort amongst ordinary production workers, particularly interns and temporary workers, was widespread, but that this did rarely translate into openly voiced discontent or work stoppages. ${ }^{27}$ Quality circles, however, were according to both workers and management largely dysfunctional due to a lack of participation, which was compensated for by union-organised skill contests and prizes for particularly productive workers. Overall, labour relations in the Company X's Chinese plants were rather stable, although they were hierarchical, unilaterally top-down organised and offered little participation or autonomous work organisation to workers.

\footnotetext{
${ }^{27}$ At JV1 a two-hour strike occurred in 2011 to demand improved pay for dispatch workers (interview JV1DW1,2); protest was openly voiced in online forums after the lethal accident of a worker on the shop floor in 2009 (Online forums baidu tieba; interviews JV1FW2; JV1DW1,2); and at JV2 workers protested against excessive overtime in 2009 (interview JV2FW1,2).
} 


\section{3. $\quad$ Training}

In both Mexico and China Company X was confronted with an incompatibility of the respective national education system and the skills demanded on the shop floor. And in both cases did it adopt training schemes broadly modelled after the experience of its operations in Germany.

In Mexico the plant had established its own on-the-job training processes and a vocational school. In the latter Company X trained specialists in an $80 \%$ technical, $20 \%$ theoretical scheme adopted from the German dual education system. In 2012 Company X had extended its facilities by another large training centre for workers to be employed at newly opened production sites, in particular its upscale brand plant that opened in 2016. Students of the vocational school were partly trained for Company X's own demand in high-skilled workers, and partly for its suppliers of the nearby industrial park. Only recently has Company X joined a certification scheme of the German Chamber of Commerce that makes these degrees transferrable. ${ }^{28}$

There were essentially two options to become a specialist worker at Company X in Mexico. New entrants could be hired as specialists if they were graduates from a (preferably Company X's) vocational school. To this end Company X offered scholarships to graduates of (the better) high schools in the area. Ordinary workers on the other hand were usually required to have a high school degree and received a basic training on the job, under rules stipulated in the Collective Contract and monitored closely by union personnel. However, if they received good performance evaluations and qualified for a company-internal scholarship, they could train to become a specialist concurrent with their (reduced) participation in normal productive operations. Workers could also access noncomprehensive individual courses if they gained particular premiums through good work performance. ${ }^{29}$

In China, Company X did not establish its own vocational schools, but hired graduates from Chinese polytechnic high schools and colleges and trained them in in-house processes. Separate rooms on the shop floor of the respective departments should allow for training in basic skills; and in advanced skills where a "professional training room" was available. The training range at JV2's main plant, for example, covered product and automation technology, project management, lean training, design, management training and foreign languages..$^{30}$

\footnotetext{
${ }^{28}$ I thank Judith Wiemann and an anonymous reviewer for clarifying this point.

${ }^{29}$ Interview worker MPW4.

${ }^{30}$ At JV1 certain training aspects have been concentrated at particular locations - one of the newer plants in the East, for example, is responsible for all aspects of lean training.
} 
Jürgens and Krzywdzinski (2015) describe in detail the pathways open to ordinary workers and skilled professionals in pursuit of an "expert" career within the enterprise. My observations and interviews confirm that the shortage of - and related need to retain - skilled personnel explains the development of expert career tracks for a minority of workers. However, this should not mislead to the assumption that there was widespread general training or strong imperatives of "lean production". The aspects of a lean system that would have demanded worker involvement were only partially applied at Company X in China (indicated above by the teamwork system). Active participation beyond following job instructions, as well as high skill levels, were demanded from a small section of the workforce only. Instead, Company X's rapid expansion in China necessitated a constant intake of new workers for simple manual tasks associated with the strongly Taylorised production process and limited model range that allowed for production lines being used for one or two models only. All new workers received a basic training in motoric functions; the operation of certain tools; techniques to avoid production mistakes; how to fill in operative sheets etc. But for dispatch workers and interns it could be drastically reduced. Dispatch workers at JV2 were supposed to be trained for two to four weeks before they were successively integrated into regular work teams, depending on models, particular tasks and learning capacity of the individual worker. In fact, however, their training was often cut short to a few days, before they were used in normal operations. ${ }^{31}$ As a German senior manager simply put it: "it is learning by doing."32

This issue entered a vicious circle, because not only did workers complain about the monotony of work, but migrant dispatch workers, who still had access to a plot of land in the countryside, where likely to leave the plant after receiving their annual bonuses. ${ }^{33}$ This section of the workforce was a minority only, which did not drive the turnover rate amongst dispatch workers beyond $10 \%$, but it fostered the segmentation of skill development. Moreover, and more generally, the content of basic training schemes was not comprehensive, but geared towards the demanded productive operations. This allowed for the reduction of training times for workers designated for simpler operations. In other words, Company X in both cases, but particularly in China, tried to keep training limited for those sections of the workforce that were most likely to leave voluntarily and/or functioned as a buffer in times of economic downswings.

\footnotetext{
${ }^{31}$ Interviews migrant dispatch workers JV2MDW5,6; German senior manager JV2GM3 (1).

32 Interview JV2GM3 (1).

${ }^{33}$ Interviews JV2MDW5,6; JV1DW3.
} 


\section{Convergence - Managerial prerogatives on the technological composition of the production process}

Finally, there are also areas of the production process, where worker agency was virtually absent or of little effect. This concerned in particular the technological composition of the production process that was in both cases fully determined by managerial decision-making, with little possibility for workers to alter it, once it had been implemented.

Company X makes extensive use of shared platforms and modular production, with the aim of achieving higher economies of scale and the ability to produce each model at every location. The pressure on a homogenisation of technological and operational processes across different plants is therefore high. On the one hand, certain machinery, such a laser welding for the roof of the car, has to be - and was - present at all plants producing state of the art models. The definition of the same welding points across sheet metal parts of different size and shape on the other hand allows for a further standardisation of tasks that workers have to fulfil. Overall, employed technology and tasks were very similar between different factories and between Mexico and China - with two exceptions. First, plants in China that continued to produce older models, which would sell due to the closed domestic market and large public orders, would manufacture these models with outdated technology. In 2013 the first press line that was relocated from the closed US production facility in the late 1980s was just being dismantled at JV2 it had been used to produce a 1980s model until 2012. Secondly, automation was handled much more flexibly in China than in Mexico, although these adaptations took place in essentially one department only: the body shop. Automation rates in the body shop for some older models in China could be as low as $29 \%$, and did not exceed $70 \%$ even for state of the art models. ${ }^{34}$

This convergence, as well as the lower and more varied automation rates in China, was explicable by unilateral management decisions, as its prerogative over the implementation of technological changes was unchallenged in both cases. In the 1992 conflict the Mexican union had lost both its institutionalised right and the rank and file power to de facto veto transformations of production technology. After this date, decisions on technological change were, as in the Chinese case, at the unilateral discretion of management; and my interviews with union representatives and workers gave no indication of a political challenge of this fact. This also implies that the divergence in automation rates between the Mexican and Chinese case has less to do with industrial relations than with managerial considerations of cost, quality, quantity, model range etc. - and with the construction date of the respective plant. Indicated by the deployment of state of

\footnotetext{
${ }^{34}$ Author's field notes.
} 
the art technology with the erection of new plants, younger Chinese plants will most likely see an increase in automation over time, with the phasing out of older models, rising wages and growing pressure on productivity. These dynamics had already been present for decades in the Mexican case, and intensified with NAFTA.

\section{Conclusion}

I have argued that hybridization or convergence and divergence between the actual operations of subsidiaries of transnationally operating car manufacturers are not mere expressions of different structural factors and institutional constraints, but essentially depend on the question of what social agents "actually do" with them. I have made two interrelated arguments. First, the watershed event of the 1992 conflict in Mexico demonstrates that approaches based on ideal-type construction lack the capacity to properly explain institutional change. Instead, the new institutional matrix that emerged after 1992 is better understood and analysed as a specific outcome of processes of relational agency between managers/policy makers and workers.

Second, I have acknowledged the virtue of static typologies in comparing the different shop floor arrangements that characterise the production process and employment relations in the Mexican and Chinese subsidiaries of Company X. I have then, however, shown that the institutions themselves are mere potentiality, realised only when acted upon by managers and workers. The direction of the effects of this agency is however less clear and not easy to predict - meritocratic remuneration systems in China and Mexico worked differently due to routinized wage bargaining in the latter case; a stalemate between workers and managers over task and time allocation emerged in Mexico due to a "state of inconformity" in the workforce; and in China exit strategies of dispatch workers and the segmentation of training schemes entered into a mutually reinforcing dynamic. These outcomes in institutional functions were not deducible from the institutional design per se - which implies that there is no way around analysing the actual agency of all stakeholders involved in more detail. This could only be done to a limited degree here - in particular the short- and long-term effects of the 1992 conflict warrant more attention.

Finally, the argument established should not be misunderstood as voluntarist: institutions and structures do matter, because they can provide the medium through which relational agency unfolds - they can be conceived as "idle capacity" for agency. Similarly, the argument of this article is not a claim to reduce hybridization or convergence/divergence to the impact of worker agency - the agency of managers and policy makers clearly matters, and is likely to still have a more decisive impact on the outcome of processes of relational agency, due to a 
higher ability to mobilise institutions and structures in their interest. The point remains, however, that this agency does not unfold in a social vacuum, but in relation to that of non-elite social groups - and that an adequate explanation of social and institutional change in their concrete forms therefore requires the inclusion of these forms of agency. While the virtues of comparative institutionalist approaches are undeniable, a more agency-centric theory of institutional change and its methodological mirror image in the form of a labourinclusive research agenda appear as promising avenues for future theoretical and empirical research.

\section{Bibliography}

Abo, T. ed., 1994. Hybrid factory. The Japanese Production System in the United States, New York: Oxford University Press.

Babson, S. ed., 1995. Lean work: empowerment and exploitation in the global auto industry, Detroit: Wayne State University Press.

Becker-Ritterspach, F.A.A., 2009. Hybridization of MNE Subsidiaries. The Automotive Sector in India, Basingstoke, New York: Palgrave Macmillan.

Bennett, D.C. \& Sharpe, K.E., 1985. Transnational corporations versus the state: the political economy of the Mexican auto industry, Princeton: Princeton University Press.

Boyer, R. et al. eds., 1998. Between imitation and innovation: The transfer and hybridization of productive models in the international automotive industry, Oxford, New York: Oxford University Press.

Boyer, R., 1998. Hybridization and Models of Production: Geography, History, and Theory. In R. Boyer et al., eds. Between imitation and innovation: The transfer and hybridization of productive models in the international automotive industry. Oxford, New York: Oxford University Press, pp. 2356.

Boyer, R. \& Freyssenet, M., 2002. The productive models: the conditions of profitability, Basingstoke, New York: Palgrave Macmillan.

Chan, C.K.-C., 2014. Constrained Labour Agency and the Changing Regulatory Regime in China. Development and Change, 45(4), pp.685-709.

Chin, G.T., 2010. China's automotive modernization: the party-state and multinational corporations, Basingstoke, New York: Palgrave Macmillan.

Covarrubias, A., 2014. Explosión de la Industria Automotriz en México: De sus encadenamientos actuales a su potencial transformador, Mexico City: Friedrich Ebert Stiftung México. 
Cremer, A. \& Funakoshi, M., 2015. Volkswagen overtakes Toyota as world's biggest carmaker. Reuters. Available at: http://www.reuters.com/article/us-toyota-salesidUSKCN0Q805F20150803 [Accessed December 7, 2015].

Elfström, M. \& Kuruvilla, S., 2014. The Changing Nature of Labor Unrest in China. Industrial and Labor Relations Review, 67(2), pp.453-480.

Freyssenet, M. ed., 2009. The second automobile revolution: trajectories of the world carmakers in the 21st century, Basingstoke, New York: Palgrave Macmillan.

Hancké, B., 2009. Introducing the Debate. In B. Hancké, ed. Debating varieties of capitalism: a reader. Oxford: Oxford University Press, pp. 1-17.

Healy, T., 2008. Gendered Struggles against Globalisation in Mexico, Aldershot, Hampshire: Ashgate.

Hollingsworth, J.R. \& Boyer, R., 1997. Coordination of Ecomnomic Actors and Social Systems of Production. In J. R. Hollingsworth \& R. Boyer, eds. Contemporary Capitalism: The Embeddedness of Institutions. Cambridge: Cambridge University Press, pp. 1-47.

Juárez Núñez, H., 2006. Global Production and worker response: The struggle at Volkswagen of Mexico. WorkingUSA, 9(1), pp.7-28.

Juárez Núñez, H., 1993. Los sindicatos frente a las políticas empreseriales de elevación de la productividad. In E. de la Garza Toledo \& C. García, eds. Productividad: distintas experiencias. Mexico City: Universidad Autónoma Metropolitana, Friederich Ebert Foundation, pp. 139-147.

Juárez Núñez, H., Bueno, C. \& Rivero, A.A.L. eds., 2005. El Auto global: desarrollo, competencia y cooperación en la industria del automóvil, Puebla: Consejo Nacional de Ciencia y Tecnología.

Jürgens, U., 2009. The Final Chapter of the "VW Model”? The VW Trajectory, 1995-2005. In M. Freyssenet, ed. The second automobile revolution: trajectories of the world carmakers in the 21st century. Basingstoke, New York: Palgrave Macmillan, pp. 225-245.

Jürgens, U. \& Krzywdzinski, M., 2015. Competence development on the shop floor and industrial upgrading: case studies of auto makers in China. The International Journal of Human Resource Management, 26(9), pp.12041225.

Jürgens, U. \& Krzywdzinski, M., 2016. New Worlds of Work. Varieties of Work in Car Factories in the BRIC Countries, Oxford, New York: Oxford University Press. 
Jürgens, U., Malsch, T. \& Dohse, K., 1989. Moderne Zeiten in der Automobilfabrik: Strategien der Produktionsmodernisierung im Länder- und Konzernvergleich, Berlin: Springer.

Kochan, T.A., Lansbury, R.D. \& Macduffie, J.P. eds., 1997. After lean production: evolving employment practices in the world auto industry, Ithaca: ILR Press.

Kostova, T. \& Roth, K., 2002. Adoption of an Organizational Practice by Subsidiaries of Multinational Corporations: Institutional and Relational Effects. The Academy of Management Journal, 45(1), pp.215-233.

Kumon, H. \& Abo, T. eds., 2004. The Hybrid Factory in Europe. The Japanese Management and Production System Transferred, Basingstoke, New York: Palgrave Macmillan.

Lüthje, B., Luo, S. \& Zhang, H., 2013. Beyond the iron rice bowl: regimes of production and industrial relations in China, Frankfurt a.M.: Campus.

Mahoney, J., 2000. Path dependence in historical sociology. Theory \& Society, 29(4), p.507.

Meng, X., 2000. Labour market reform in China, Cambridge, New York: Cambridge University Press.

Montiel, Y., 2001. Un mundo de coches: Nuevas formas de organización del trabajo. Estudios de caso, Mexico City: CIESAS.

North, D.C. \& Weingast, B.R., 1989. Constitutions and Commitment: The Evolution of Institutions Governing Public Choice in Seventeenth-Century England. Journal of Economic History, 49(4), p.803.

Pries, L., 1993. Volkswagen ¿Un nudo gordiano resuelto? Trabajo. Sociedad, Tecnología y Cultura, (9), pp.7-23.

Pringle, T., 2011. Trade unions in China: the challenge of labour unrest, Abingdon, New York: Routledge.

Schaper, N., 2014. Gruppenarbeit in der Produktion. In Arbeits- und Organisationspsychologie. Berlin, Heidelberg: Springer, pp. 393-417.

Streeck, W., 1992. Social institutions and economic performance: studies of industrial relations in advanced capitalist economies, London: Sage.

Streeck, W. \& Kenworthy, L., 2005. Theories and Practices of Neocorporatism. In T. Janoski et al., eds. The handbook of political sociology: states, civil societies, and globalization. Cambridge, New York: Cambridge University Press. 
Thun, E., 2006. Changing Lanes in China: Foreign Direct Investment, Local Government, and Auto Sector Development, Cambridge, New York: Cambridge University Press.

Weber, M., 1988. Gesammelte Aufsätze zur Wissenschaftslehre, Tübingen: Mohr.

Weingast, B.R., 2002. Rational-choice institutionalism. In I. Katznelson \& H. V. Milner, eds. Political science: state of the discipline. New York: Norton.

Wenten, F., 2016. Reinventing the wheel - Labour, development and global car production in post-1970s China and Mexico. London: School of Oriental and African Studies (SOAS).

Womack, J.P., Jones, D.T. \& Roos, D., 1990. The Machine That Changed the World: How Japan's Secret Weapon in the Global Auto Wars Will Revolutionize Western Industry, New York: Rawson Associates.

Zhang, L., 2014. Inside China's automobile factories: the politics of labor and worker resistance, Cambridge, New York: Cambridge University Press. 